\title{
Experimental Investigations on the Mechanical Properties, Microstructure and Corrosion Resistance of Cu-20Al-4Ni/SiC Composites Synthesized Using Powder Metallurgy
}

Mamundi Azaath L ( $\square$ azaathphd@gmail.com )

Mount Zion College of Engineering and Technology

Natarajan U

Alagappa Chettiar Government College of Engineering and Technology

Veerappan G

Vickram College of Engineering

Ravichandran $\mathbf{M}$

K Ramakrishnan College of Engineering

Marichamy S

Sri Indu College of Engineering \& Technology

\section{Research Article}

Keywords: Bronze composite, Sinterability, Powder metallurgy, Silicon carbide, Corrosion

Posted Date: May 26th, 2021

DOI: https://doi.org/10.21203/rs.3.rs-514167/v1

License: (c) (i) This work is licensed under a Creative Commons Attribution 4.0 International License.

Read Full License 


\section{Abstract}

The present investigation pertains to synthesize aluminium bronze silicon carbide composite by powder metallurgy route. Three various weight percentages of silicon carbide $(0,2,4 \& 6)$ were reinforced with aluminium bronze matrix ( $\mathrm{Cu}-20 \% \mathrm{Al}-4 \% \mathrm{Ni})$ and the hydraulic press was used to prepare the green compact. This compact was heated at two different temperatures such as $650^{\circ} \mathrm{C}$ and $750^{\circ} \mathrm{C}$ using tubular furnace. The effect of silicon carbide on density, sinterability, compression test and hardness test was analyzed. The scanning electron microscope and energy dispersive spectroscopy were used to confirm the presence of alloying elements. The results showed that the sinterability and density were reduced with an increase in silicon carbide content. The composite reinforced with $6 \% \mathrm{SiC}$ exhibited lowest compressive strength among other composites. The $4 \mathrm{wt}$.\% SiC reinforced composites sintered at $750^{\circ} \mathrm{C}$ has highest corrosion resistance.

\section{Introduction}

Metal matrix composite (MMC) is a composite material made up of a matrix and reinforcement material that has been combined to enhance mechanical, thermal, and physical properties. The need for better strength and corrosion resistance has pulled MMC in desired zone of manufacturing company. Composites have been used for aerospace, electronics and marine applications because they have a number of required and variable properties, such as high stiffness, high temperature resilience, increased wear resistance, and a low coefficient of thermal expansion.

Various techniques are used for production of composite depend upon reinforcement such as compo casting [1], liquid phase infiltration [2], squeeze casting and spray co-deposition [3].

Casting process has many hindrances due to some reasons such as non uniform dispersal of reinforcement in matrix, adverse reaction between matrix and reinforcement at high temperature, and heterogeneous matrix structure. Because of these constraints, bulk mechanical properties were affected as a result of differences between the strengthening and the matrix. These problems became more relevant as a result of these constraints $[4,5]$. Considering these disadvantages, powder metallurgy (PM) is the apt method for production of composite. Particulate-reinforced composites prepared by PM have better properties with augmented metal working character which is the defined method for producing composite materials [6].

Common reinforcements added to the matrix are $\mathrm{SiC}, \mathrm{B}_{4} \mathrm{C}$, graphite, $\mathrm{NbC}, \mathrm{TaC}, \mathrm{TiB}, \mathrm{TiB}_{12}, \mathrm{TiC}, \mathrm{WC}, \mathrm{Mo}$, and $\mathrm{Al}_{2} \mathrm{O}_{3}$. SiC is the commercial reinforcement material added to the matrix in large volume followed by $\mathrm{Al}_{2} \mathrm{O}_{3}$ and $\mathrm{TiC}$. The addition of particulates such as $\mathrm{SiC}, \mathrm{B} 4 \mathrm{C}, \mathrm{MgO}, \mathrm{TiC}$ and $\mathrm{ZnO}$ could drastically reduce the wear rate. Since the addition of $\mathrm{SiC}$ reinforcement strengthens the properties and reduces wear intensity, SiC particle is the most widely used [7]. 
Copper $(\mathrm{Cu})$ is the most commonly used powdered alloying material due to its easy availability, cheap and potential to augment alloy properties. Cu powder has the potential to mix ready with master alloy, alloying elements, lubricants and graphite. Cu has a major impact on the material's mechanical properties. Cu reaches liquidus stage at $1083^{\circ} \mathrm{C}$ and widely spreaded well in the alloy. As an effect, $\mathrm{Cu}$ fills pores in the resulting alloys, increasing hardness and density [8]. Further addition of $\mathrm{Cu}$ with proportion of martensite yielded in enhanced tensile strength-ductility for balance of alloys containing 04 wt. \% Cu [9]. Lowhaphandu et al. [10] analyzed the impact of inclusion of $10 \mathrm{wt}$. \% Cu infiltration on 2D fracture resistance and fracture crack growth performance of PM-processed porous plan carbon steels subjected to various heat treatment conditions. From the polarization curve it was clearly indicated that the $99.5 \%$ bronze added with $3 \%$ of $\mathrm{SiC}, \mathrm{SiO}_{2}$, and $1.5 \%$ of $\mathrm{C}$ has highest corrosion wear rate of $0.05 \mathrm{~mm} /$ $\mathrm{yr}$ at the potential value of $-284 \mathrm{mV}$ in artificial acid rain condition [11].Abu et al [12 ] investigated Al2024 alloy powders having $160 \mu \mathrm{m}$ were mixed with different weight percentage of graphene sheet with $0 \%$, $0.25 \%, 0.5 \%, 1 \%$, and $2 \%$ to prepare specimen with the diameter of $20 \mathrm{~mm}$ having $6 \mathrm{~mm}$ length. It was prepared at $40 \mathrm{Mpa}$ at the sintering temperature of $460^{\circ} \mathrm{C}$ and $560^{\circ} \mathrm{C}$ in open argon gas atmosphere condition. In the corrosion test the graph clearly indicates that corrosion rate seems very less with increasing with the percentage of graphene in the specimen. Aluminium with $2 \%$ graphene has maximum corrosion resistance at different exposure time compared with other specimen.

CuAl10Ni5Fe4 alloy powders were milled in Fritsch Pulverisette 6 model. Different milling times 0.5 to 40 hours were involved to create the specimen under the pressure of $700 \mathrm{Mpa}$. Sintering temperature was used in this investigation at $900^{\circ} \mathrm{C}$ for duration of $90 \mathrm{~min}$. Electrochemical test were carried out with presence of $3.5 \% \mathrm{NaCl}$ solution to calculate corrosion rate for the specimen under open atmospheric condition. From this corrosion test for the samples under as-cast and powder metallurgy methods, polarization curve indicates that the samples produced under powder metallurgy has massive corrosion resistance than the as-cast samples [13].Pure magnesium and magnesium powder with $10 \mathrm{wt} . \%$ of $\mathrm{Al}, 20$ wt.\% of Al, 50 wt.\% of Al were used to prepare the specimen using milling method with the milling time of 2 hours, pressure of $300 \mathrm{Mpa}$ at a sintering temperature of $500^{\circ} \mathrm{C}$ for 1 hour. Sintering process was carried out in the tubular furnace under argon gas environment. Corrosion behavior of the samples was estimated for the samples which are immersed in $3.5 \%$ weight percentage of $\mathrm{NaCl}$ solution. By the polarization curve it was seems that increase in wt. \% of aluminium increases the corrosion resistance of the samples [14].

Very limited investigation related to synthesis of bronze composites was found out. The present experimental work focuses on synthesizing of aluminium bronze-SiC composites and analyzing the effect of silicon carbide and sintering temperature on density, hardness, compressive strength, sinterability, and corrosion behavior on synthesized composites. The composites were also subjected to SEM and Energy Dispersive spectroscopy (EDS) analysis.

\section{Materials And Methods}




\subsection{Synthesis of silicon carbide reinforced aluminium bronze composite}

Aluminium bronze (Cu-20\%Al-4\% Ni) powder of purity $99.7 \%$ was the matrix material and silicon carbide was the reinforcement. The SEM results of bronze powder and silicon carbide are shown in Fig. 1. Three different weight proportion of silicon carbide $(0,2,4 \& 6 \mathrm{wt}$. \%) are reinforced with Cu-20Sn using powder metallurgy. The required weight proportion of $\mathrm{Cu}-20 \% \mathrm{Al}-4 \% \mathrm{Ni}$ and $\mathrm{SiC}$ were mixed using ball milling for 1 hour. Toluene was mixed with powder as lubricant and cold fusion of different powder was achieved prior to sintering because of using ball to powder ratio as 10:1 [15].

The phase identification for the ball milled powders were found using $X$ ray diffraction equipment for the ball milled powders with various proportions of $\operatorname{SiC}(0,2,4 \& 6 \mathrm{wt}$. \%). Scan speed of $0.01 \%$ s was used to determine the phase identification with Cu-Ka radiation $\left(\lambda=1.54060 \mathrm{~A}^{\circ}\right)$. Figure.2a represents the presence of $\mathrm{Cu}$ with higher intensity peaks than other elements such as $\mathrm{Fe}, \mathrm{Ni}$ and $\mathrm{Zn}$. The corresponding peaks of $\mathrm{SiC}$ were clearly noticed to be increased with an increase in SiC content as shown in Figure.2 (bc). The ball milled powder was compacted to cyclindrical green compact rod of diameter $20 \mathrm{~mm}$ and the height $15 \mathrm{~mm}$ using hydraulic press of capacity $250 \mathrm{kN}$ with an appropriate set of punch and die. Green compacts were coated with suitable coating to harness the oxidation effect in order to obtain defect free compact. The compacts were sintered at two different temperatures: (a) $650^{\circ} \mathrm{C}$ (b) $750^{\circ} \mathrm{C}$ using tubular furnace of maximum capacity $1300^{\circ} \mathrm{C}$. The heating rate for sintering was $5^{\circ} \mathrm{C}$ per minute and hold duration was 30 minutes. The sintered sample was shown in Fig. 3. According to ASTM E110, the rockwell hardness of the sintered composites was found out using Rockwell hardness machine. The compression test was carried out as per ASTM E9 standard.

The corrosion characteristic of synthesized composites was analyzed using potentio dynamic polarization experiment using electrochemical workstation with three electron setup. Aluminium bronze composite sintered compacts, $\mathrm{AgCl}$, platinum wired were used as working electrode, reference electrode and counter electron respectively. The compacts were polished using an 800 grit emery and rinsed to remove greasy item using acetone. The $5 \% \mathrm{NaCl}$ solution was prepared and electrodes were dipped in the prepared solution. The polarization test was carried out at specified rate of $1 \mathrm{mVs}^{-1}$. $[16,17,18]$

\section{Results \& Discussions}

\subsection{SEM analysis of sintered aluminium bronze composites}

Figure $4 \mathrm{a}$ and $\mathrm{b}$ shows the SEM results of, sintered aluminium bronze $-2 \mathrm{wt}$.\% SiC composite sintered at $650^{\circ} \mathrm{C}$ and sintered aluminium bronze $-2 \mathrm{wt} . \% \mathrm{SiC}$ composite $750^{\circ} \mathrm{C}$ respectively. Homogeneous wide spread of $\mathrm{SiC}$ in the bronze matrix along with micro pores as shown in Figure 3a. However, the pores formation increases with an increase in $\mathrm{SiC}$ reinforcement. Pore formation is the cause of more $\mathrm{SiC}$ content effectively restrains the grain boundary diffusion paths between the bronze powder particles [19]. 
Figure $4 \mathrm{~b}$ shows the absence of voids in the microstructure and the distribution of SiC particles throughout the matrix is uniform. The higher sinter temperature caused better bonding strength between matrix and reinforcement. It was observed that microstructure witnessed absence of agglomeration and clusters. Figure $4 \mathrm{c}$ shows the microstructure of sintered aluminium bronze $-4 \mathrm{wt}$ \% $\mathrm{SiC}$ composite sintered at $750^{\circ} \mathrm{C}$ From Figure 4c, it was noticed that entrenchment of $\mathrm{SiC}$ particles in bronze matrix due to the better interfacial bonding between matrix and reinforcement. Figure.5 (a-c) shows EDS results of sintered aluminium bronze composites. The presence of elements such as $\mathrm{Cu}, \mathrm{Al}, \mathrm{Fe}, \mathrm{Ni}$ and $\mathrm{SiC}$ are confirmed by EDS results as shown in the same figure. Figure.5 (a-c) shows that SiC peaks are adjacent to copper peaks which point out that silicon carbide particulates are embedded with copper matrix. The entrapped of oxygen was confirmed by presence of corresponding peak in EDS result.

\subsection{Effect of silicon carbide and sintering temperature on density of aluminium bronze matrix}

Figure. 6 reveals the densification characteristics of composites sintered at $650{ }^{\circ} \mathrm{C}$ and $750{ }^{\circ} \mathrm{C}$. The green density of the composites decreases linearly up to composites containing $4 \mathrm{wt}$.\% SiC and subsequent addition of $6 \mathrm{wt} . \% \mathrm{SiC}$ descends down drastically. In the same way, sintered densities of the composites were observed to decrease linearly with an increase in SiC reinforcement. Addition of $2 \% \mathrm{SiC}$ particle leads to decrease in green density, sintered density at $650^{\circ} \mathrm{C}$ and sintered density at $750^{\circ} \mathrm{C}$ by $4.12 \%$, $6.02 \%$ and $5.72 \%$, respectively. Furthermore, inclusion of $4 \% \mathrm{SiC}$ over aluminium bronze alloy leads to decrease in green density, sintered density at $650^{\circ} \mathrm{C}$ and sintered density at $750^{\circ} \mathrm{C}$ by $8.33 \%$ and $5.82 \%$, respectively. The sintered density possesses high density than that of green compact density, because green compacts have voids and this could be the main cause for the lower density. The void formation rise across the formulation due to the decrease in wettability by the addition of particulates [20]. The composite sintered at $750^{\circ} \mathrm{C}$ possesses higher sintered density than composite sintered at $750^{\circ} \mathrm{C}$ Increased contents of reinforcements obstructs the dislocation movements which tends to an increase in dislocation density [21].

\subsection{Effect of silicon carbide and sintering temperature on hardness and compressive strength of aluminium bronze matrix}

It is clearly observed that unreinforced aluminium bronze sintered at $650^{\circ} \mathrm{C}$ possesses lowest hardness (23 HRC) among the four PM aluminium bronze composites. The hardness values for the sintered composites at $750^{\circ} \mathrm{C}$ are higher than the composites sintered at $650^{\circ} \mathrm{C}$ which is represented in Figure.7. The hardness values increases with an increase in proportion of $\mathrm{SiC}$ up to $4 \%$, then hardness decreases. The composite (4 wt.\% SiC) exhibits highest hardness of 32HRC. The increase in hardness may be attributed to the combined effect of particulates and a smaller matrix grain size [22]. This is due to the better bonding between matrix and reinforcement which is evident in Figure.4c. The variations in hardness values among the four composites are not very significant. The maximum percentage of increase in hardness was $11.1 \%$, which was noticed for $2 \% \mathrm{SiC}$ reinforced aluminium bronze. The compressive strength increases linearly with an increase in $\mathrm{SiC}$ material, as shown in Figure.8.There is slight rise in compressive strength with an increase in sintering temperature. Maximum compressive 
strength of $490 \mathrm{Mpa}$ was observed for $4 \%$ reinforced composites, which was sintered at $750^{\circ} \mathrm{C}$. Subsequent inclusion of $\mathrm{SiC}$ causes decrease in compressive strength. As a result, the gap between reinforcements becomes less when more reinforcement added to the matrix and dislocation pile up occurs which causes reduction in elongation [23]. Among the sintered composites at $750^{\circ} \mathrm{C}, 6 \%$ reinforced composites witnessed lowest compressive strength of $400 \mathrm{MPa}$. There is not much appreciable increase in compressive strength with respect to silicon percentage.

\subsection{Effect of silicon carbide and sintering temperature on sinterability of aluminium bronze matrix composites}

Sinterability is the function of the densification process. As it is obvious from Figure.9, the inclusion of $\mathrm{SiC}$ in the bronze matrix caused sinter ability to decline. This may be due to the hindrance of reinforcement in achievement of near densification. Among the composites sintered at $750{ }^{\circ} \mathrm{C}, 6 \% \mathrm{SiC}$ reinforced possesses lowest sinterability of 0.44 which indicate lesser ability of densification. This could be due to the (a) low compressibility (b) hindrance for the metal to metal contact by reinforcement in order to prevent bonding $[24,25]$. Sintering temperature has great influence on sinterability because the overall sinterability for $750^{\circ} \mathrm{C}$ is higher than $650^{\circ} \mathrm{C}$. This is due to the higher diffusion rate at higher temperature.

\subsection{Effect of silicon carbide and sintering temperature on corrosion of the aluminium bronze matrix composites}

The compressive strength and hardness for the $6 \% \mathrm{SiC}$ reinforced composites sintered at both $650^{\circ} \mathrm{C}$ and $750^{\circ} \mathrm{C}$ possesses low values. Therefore, $6 \% \mathrm{SiC}$ reinforced composites was eliminated for corrosion investigation. The corrosion test was performed with $5 \% \mathrm{NaCl}$ solution for the specimen. Polarization graphs plotted in Figure.10 and Figure.11 indicates the parameters like potential $(\mathrm{V})$ and current $(\mathrm{A})$ which was calculated by using Tafel plots. Figure.10 (a-c) indicates the polarization curves for $0 \% \mathrm{SiC}, 2 \% \mathrm{SiC}$ and $4 \% \mathrm{SiC}$ composites sintered at $650^{\circ} \mathrm{C}$. From the figure. 8 indicates the corrosion rate was increased much better with increase in weight percentage of SiC. From the figure.11 (a-c) indicates the polarization curve for $0 \% \mathrm{SiC}, 2 \% \mathrm{SiC}$, and $4 \% \mathrm{SiC}$ composites sintered at $750^{\circ} \mathrm{C}$. $4 \% \mathrm{SiC}$ composites sintered at $750^{\circ} \mathrm{C}$ possesses superior corrosion resistance than $4 \% \mathrm{SiC}$ composites sintered at $650^{\circ} \mathrm{C}$. Because of the incorporation of $\mathrm{SiC}$, the corrosion resistance of the aluminium bronze composites improved noticeably as compared to its purest form. This improvement in corrosion resistance may be due to the proper formation of passive layer due to the $\mathrm{SiC}$ reinforcements [23]The sintering temperature has the significant role in improving the corrosion resistance. The corrosion resistance was enhanced with increase in both sintering temperature as well as reinforcement [24].

\section{Conclusion}

- Silicon carbide reinforced aluminium bronze composites was successfully synthesized using powder metallurgy. 
- XRD examination of the ball milled powders confirms the presence of $\mathrm{Cu}, \mathrm{Al}, \mathrm{Ni}$ and Silicon carbide.

- SEM results shows uniform distribution of SiC particles throughout the $\mathrm{Cu}-20 \% \mathrm{Al}-4 \% \mathrm{Ni}-4 \% \mathrm{SiC}$ composites sintered at $750^{\circ} \mathrm{C}$ and also revealed the pore formation in $\mathrm{Cu}-20 \% \mathrm{Al}-4 \% \mathrm{Ni}-2 \% \mathrm{SiC}$ composites sintered at $650^{\circ} \mathrm{C}$.

- 6 wt.\% SiC reinforced composites has lowest density of other three composites.

- The green and sintered density of Cu-20\%Al- $4 \% \mathrm{Ni}-4 \% \mathrm{SiC}$ composites sintered at $750^{\circ} \mathrm{C}$ possess better density than samples sintered at $650^{\circ} \mathrm{C}$.

- 4 wt.\% SiC reinforced composites sintered at $750^{\circ} \mathrm{C}$ possesses highest compressive strength of the other three composites. Further inclusion of $\mathrm{SiC}(6 \mathrm{wt} . \%)$ in $\mathrm{Cu}-20 \% \mathrm{Al}-4 \% \mathrm{Ni}$ matrix deteriorates compressive strength of the composites from MPa To MPa.

- The sinterability of the $\mathrm{Cu}-20 \% \mathrm{Al}-4 \% \mathrm{Ni}-\mathrm{SiC}$ composites decreases with an increase in reinforcement.

- The corrosion resistance of the $\mathrm{Cu}-20 \% \mathrm{Al}-4 \% \mathrm{Ni}-\mathrm{SiC}$ composites sintered at $750{ }^{\circ} \mathrm{C}$ was higher than Cu-20\%Al-4\%Ni- $4 \% \mathrm{SiC}$ composites sintered at $650^{\circ} \mathrm{C}$.

\section{Declarations}

The authors declare that they have no known competing financial interests or personal relationships that could have appeared to influence the work reported in this paper.

\section{Funding statement}

The authors did not receive support from any organization for the submitted work.

\section{Conflict of interest}

The authors have no conflicts of interest to declare that are relevant to the content of this article.

\section{Author contributions}

L.Mamundi Azaath: conceptualization, Methodology U.Natarajan: Supervision, G.Veerappan: Data manipulation, M.Ravichandran: review and editing, S.Marichamy- review and editing.

\section{Availability of data and material}

Data sharing not applicable

\section{Compliance with ethical standards}

The author declare that he has no known competing financial interests or personal relationships that could have appeared to influence the work reported in this paper. The authors declare that there is no conflict of interest. 


\section{Consent to participate}

Not applicable.

\section{Consent for Publication}

Yes granted.

\section{Acknowledgments}

Authors sincerely thanks to Mount Zion College of Engineering and Technology, Pudukkottai, Tamilnadu, India for providing the facilities for this research work.

\section{References}

1. Seo, Y., \& Kang, C. (1999). Effects of hot extrusion through a curved die on the mechanical properties of SiCp/Al composites fabricated by melt-stirring. Composites Science and Technology, 59(5), 643654. https://doi.org/10.1016/s0266-3538(98)00123-7

2. Xu, Y., Chung, D.D.L. Low-volume-fraction particulate preforms for making metal-matrix composites by liquid metal infiltration. Journal of Materials Science33, 4707-4709 (1998). https://doi.org/10.1023/A:1004480819365

3. Seo, Y. H., \& Kang, C. G. (1995). The effect of applied pressure on particle-dispersion characteristics and mechanical properties in melt-stirring squeeze-cast SiCp/Al composites. Journal of Materials Processing Technology, 55(3-4), 370-379. https://doi.org/10.1016/0924-0136(95)02033-0

4. Izadi, H., Nolting, A., Munro, C., Bishop, D., Plucknett, K., \& Gerlich, A. (2013). Friction stir processing of $\mathrm{Al} / \mathrm{SiC}$ composites fabricated by powder metallurgy. Journal of Materials Processing Technology, 213(11), 1900-1907. https://doi.org/10.1016/j.jmatprotec.2013.05.012

5. Cavdar, U., Atik, E., \& Akgul, M. B. (2014). Magnetic-Thermal Analysis and Rapid Consolidation of FE3 wt.\% CU Powder Metal Compacts Sintered by Medium-Frequency Induction-Heated System. Powder Metallurgy and Metal Ceramics, 53(3-4), 191-198. https://doi.org/10.1007/s11106-0149603-5

6. Varol, T., Canakci, A., \& Yalcin, E. D. (2016). Fabrication of NanoSiC-Reinforced Al2024 Matrix Composites by a Novel Production Method. Arabian Journal for Science and Engineering, 42(5), 1751-1764. https://doi.org/10.1007/s13369-016-2295-z

7. Mandal, A., Murty, B., \& Chakraborty, M. (2009). Wear behaviour of near eutectic Al-Si alloy reinforced with in-situ TiB2 particles. Materials Science and Engineering: A, 506(1-2), 27-33. https://doi.org/10.1016/j.msea.2008.11.007

8. Ye, D., Li, J., Jiang, W., Su, J., \& Zhao, K. (2012). Effect of Cu addition on microstructure and mechanical properties of $15 \% \mathrm{Cr}$ super martensitic stainless steel. Materials \& Design, 41, 16-22. https://doi.org/10.1016/j.matdes.2012.04.036 
9. Takaki, S., Fujioka, M., Aihara, S., Nagataki, Y., Yamashita, T., Sano, N., Adachi, Y., Nomura, M., \& Yaguchi, H. (2004). Effect of Copper on Tensile Properties and Grain-Refinement of Steel and its Relation to Precipitation Behavior. MATERIALS TRANSACTIONS, 45(7), 2239-2244. https://doi.org/10.2320/matertrans.45.2239

10. Lowhaphandu, P., \& Lewandowski, J. J. (1999). Fatigue and fracture of porous steels and Cuinfiltrated porous steels. Metallurgical and Materials Transactions A, 30(2), 325-334. https://doi.org/10.1007/s11661-999-0321-4

11. Ragab, K., Abdel-Karim, R., Farag, S., El-Raghy, S., \& Ahmed, H. (2010). Influence of SiC, SiO2 and graphite on corrosive wear of bronze composites subjected to acid rain. Tribology International, 43(3), 594-601. https://doi.org/10.1016/j.triboint.2009.09.008

12. AbuShanab, W. S., Moustafa, E. B., Ghandourah, E., \& Taha, M. A. (2020). Effect of graphene nanoparticles on the physical and mechanical properties of the Al2024-graphene nanocomposites fabricated by powder metallurgy. Results in Physics, 19, 103343. https://doi.org/10.1016/j.rinp.2020.103343

13. Öztürk, S., Sünbül, S. E., Metoğlu, A., \& içiN, K. (2020). Improvement of microstructure, tribology and corrosion characteristics of nickel-aluminum bronze by P/M method. Tribology International, 151, 106519. https://doi.org/10.1016/j.triboint.2020.106519

14. Alias, J. (2020). Role of Aluminium on the Microstructure and Corrosion Behavior of Magnesium Prepared by Powder Metallurgy Method. International Journal of Automotive and Mechanical Engineering, 17(3), 8206-8213. https://doi.org/10.15282/ijame.17.3.2020.14.0618

15. Veerappan, G., Ravichandran, M., Meignanamoorthy, M., \& Mohanavel, V. (2020). Characterization and Properties of Silicon Carbide Reinforced Ni-10Co-5Cr (Superalloy) Matrix Composite Produced Via Powder Metallurgy Route. Silicon, 13(4), 973-984. https://doi.org/10.1007/s12633-020-00455-9

16. Gopinath, S., Prince, M., \& Raghav, G. R. (2020). Enhancing the mechanical, wear and corrosion behaviour of stir casted aluminium 6061 hybrid composites through the incorporation of boron nitride and aluminium oxide particles. Materials Research Express, 7(1), 016582. https://doi.org/10.1088/2053-1591/ab6c1d

17. Muthukrishnan, D., Balaji, A., \& Raghav, G. (2018). Effect of Nano-TiO ${ }_{2}$ Particles on Wear and Corrosion Behaviour of AA6063 Surface Composite Fabricated by Friction Stir Processing. Metallofizika I Noveishie Tekhnologii, 40(3), 397-409. https://doi.org/10.15407/mfint.40.03.0397

18. Raghav, G., Balaji, A., Muthukrishnan, D., \& Sruthi, V. (2018). Preparation of Co-Gr Nanocomposites and Analysis of Their Tribological and Corrosion Characteristics. Metallofizika I Noveishie Tekhnologii, 4O(7), 979-992. https://doi.org/10.15407/mfint.40.07.0979

19. Rathod, S., Sharma, M., Modi, O. P., Khare, A. K., \& Prasad, B. K. (2013). Effect of aluminium addition on densification behavior and microstructural features of $\mathrm{P} / \mathrm{M}$ processed $\mathrm{Cu}-\mathrm{TiC}$ composites. International Journal of Materials Research, 104(7), 666-674. https://doi.org/10.3139/146.110911

20. Ahlatci, H., Koçer, T., Candan, E., \& Çimenoğlu, H. (2006). Wear behavior of Al/(Al2O3p+SiCp) hybrid composites. Tribology International, 39(3), 213-220. https://doi.org/10.1016/j.triboint.2005.01.029 
21. Rahimian, M., Parvin, N., \& Ehsani, N. (2011). The effect of production parameters on microstructure and wear resistance of powder metallurgy Al-Al203 composite. Materials \& Design, 32(2), 10311038. https://doi.org/10.1016/j.matdes.2010.07.016

22. Tjong, S., \& Lau, K. (1999). Properties and abrasive wear of TiB 2 /Al-4\%Cu composites produced by hot isostatic pressing. Composites Science and Technology, 59(13), 2005-2013. https://doi.org/10.1016/s0266-3538(99)00056-1

23. Abdizadeh, H., Ashuri, M., Moghadam, P. T., Nouribahadory, A., \& Baharvandi, H. R. (2011). Improvement in physical and mechanical properties of aluminum/zircon composites fabricated by powder metallurgy method. Materials \& Design, 32(8-9), 4417-4423.

https://doi.org/10.1016/j.matdes.2011.03.071

24. Elomari, S., Skibo, M., Sundarrajan, A., \& Richards, H. (1998). Thermal expansion behavior of particulate metal-matrix composites. Composites Science and Technology, 58(3-4), 369-376. https://doi.org/10.1016/s0266-3538(97)00124-3

25. Hong, S., \& Kao, P. (1989). SiC-reinforced aluminium composite made by resistance sintering of mechanically alloyed powders. Materials Science and Engineering: A, 119, 153-159. https://doi.org/10.1016/0921-5093(89)90534-0

26. Trzaskoma, P. P., McCafferty, E., \& Crowe, C. R. (1983). Corrosion Behavior of SiC / Al Metal Matrix Composites. Journal of the Electrochemical Society, 130(9), 1804-1809.

https://doi.org/10.1149/1.2120102

\section{Figures}
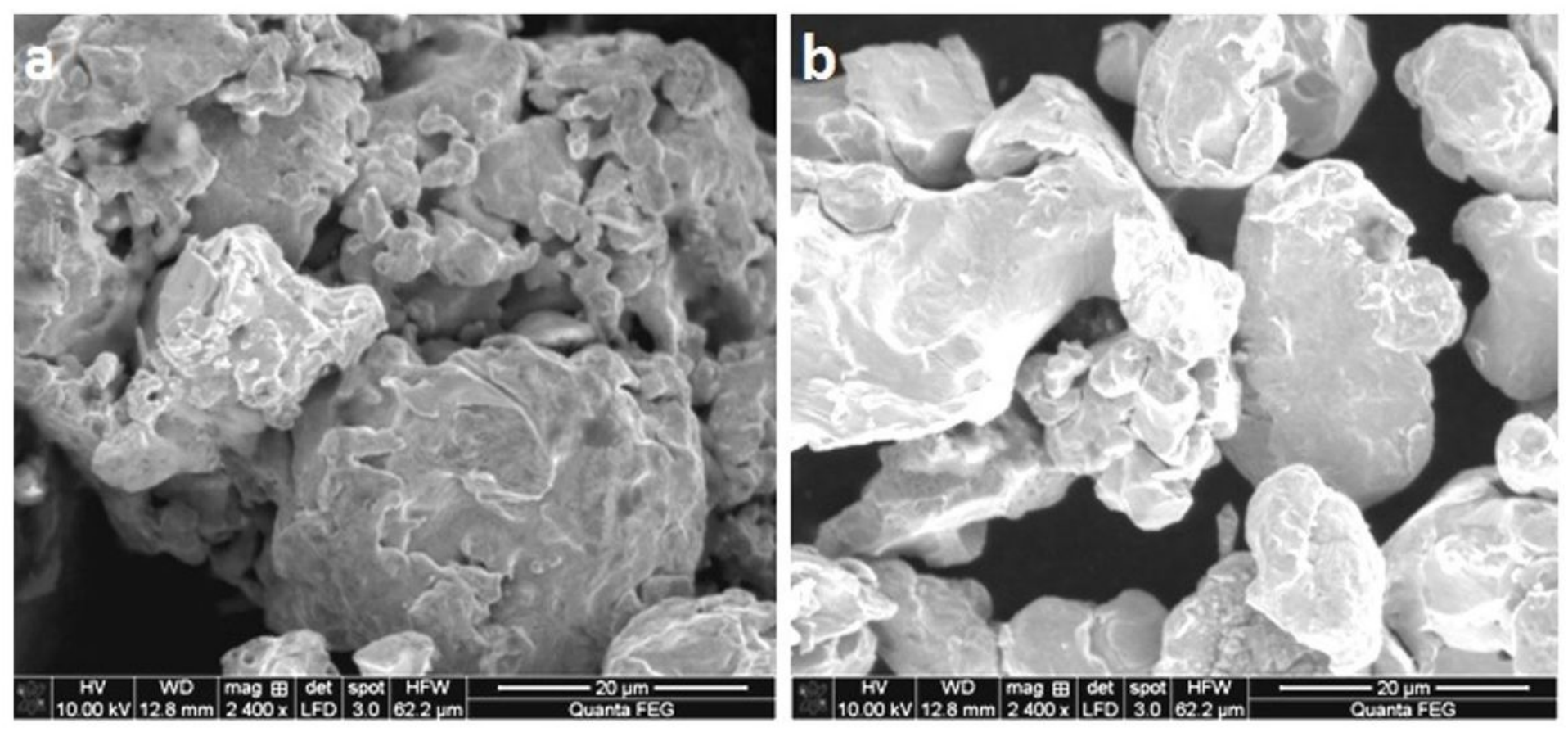

Figure 1 
SEM result of (a) Bronze powder (Cu-20\%Al-4\%Ni) (b) Silicon Carbide powder

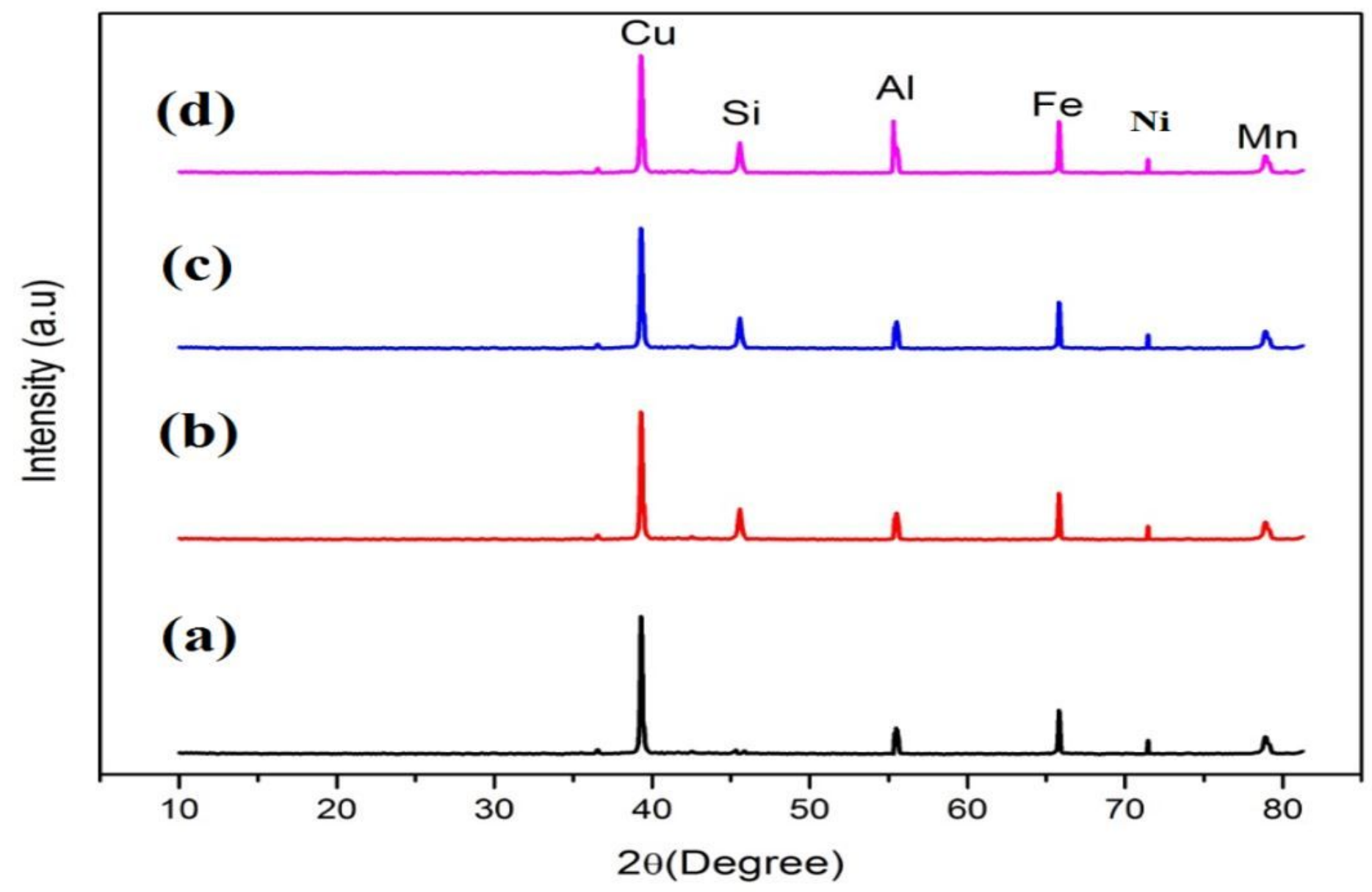

Figure 2

XRD results of sintered Aluminium bronze-SiC (0, 2, 4 \& 6 wt.\%) 


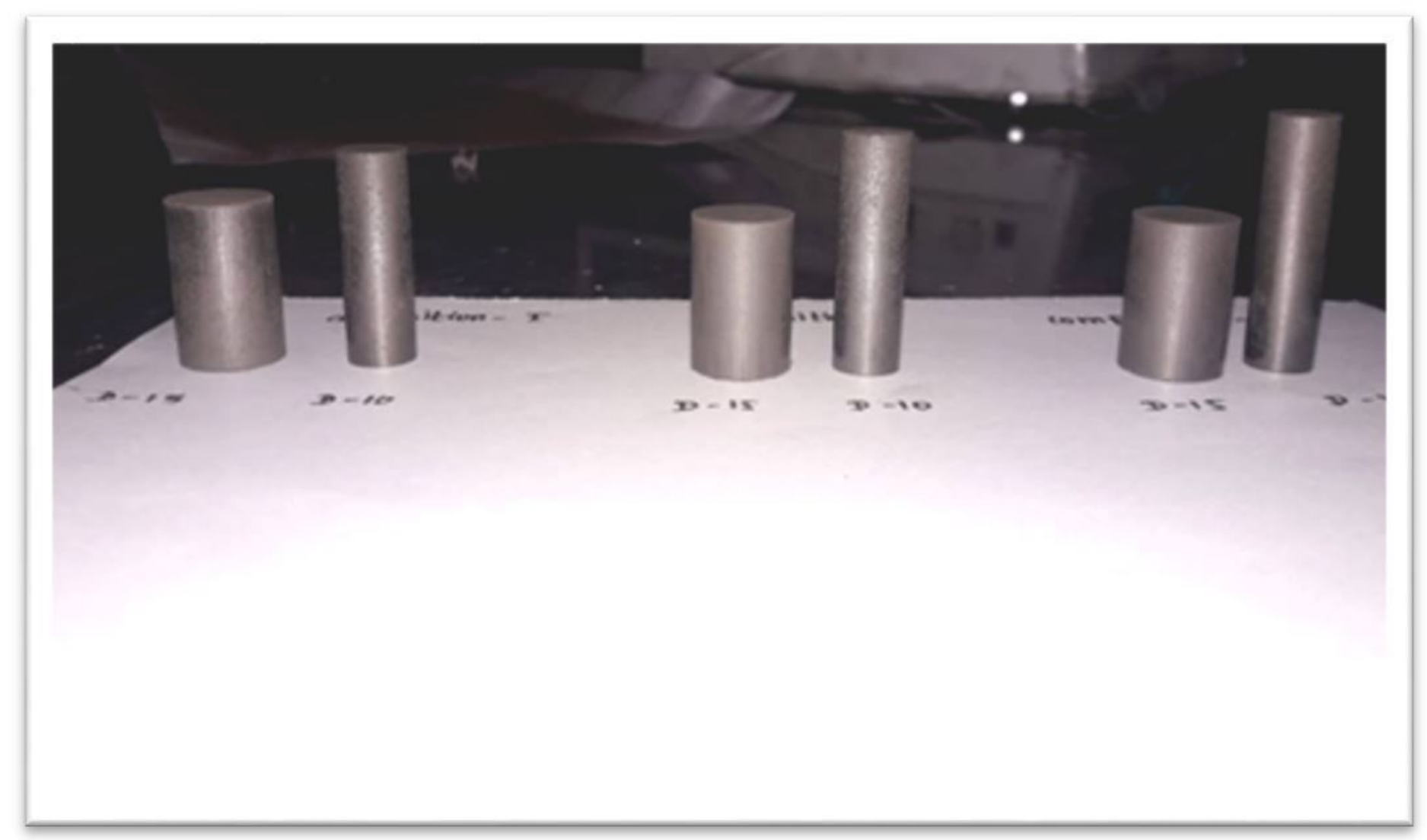

Figure 3

Sintered composites (Cu-20\%Al-4\%Ni/SiC) 

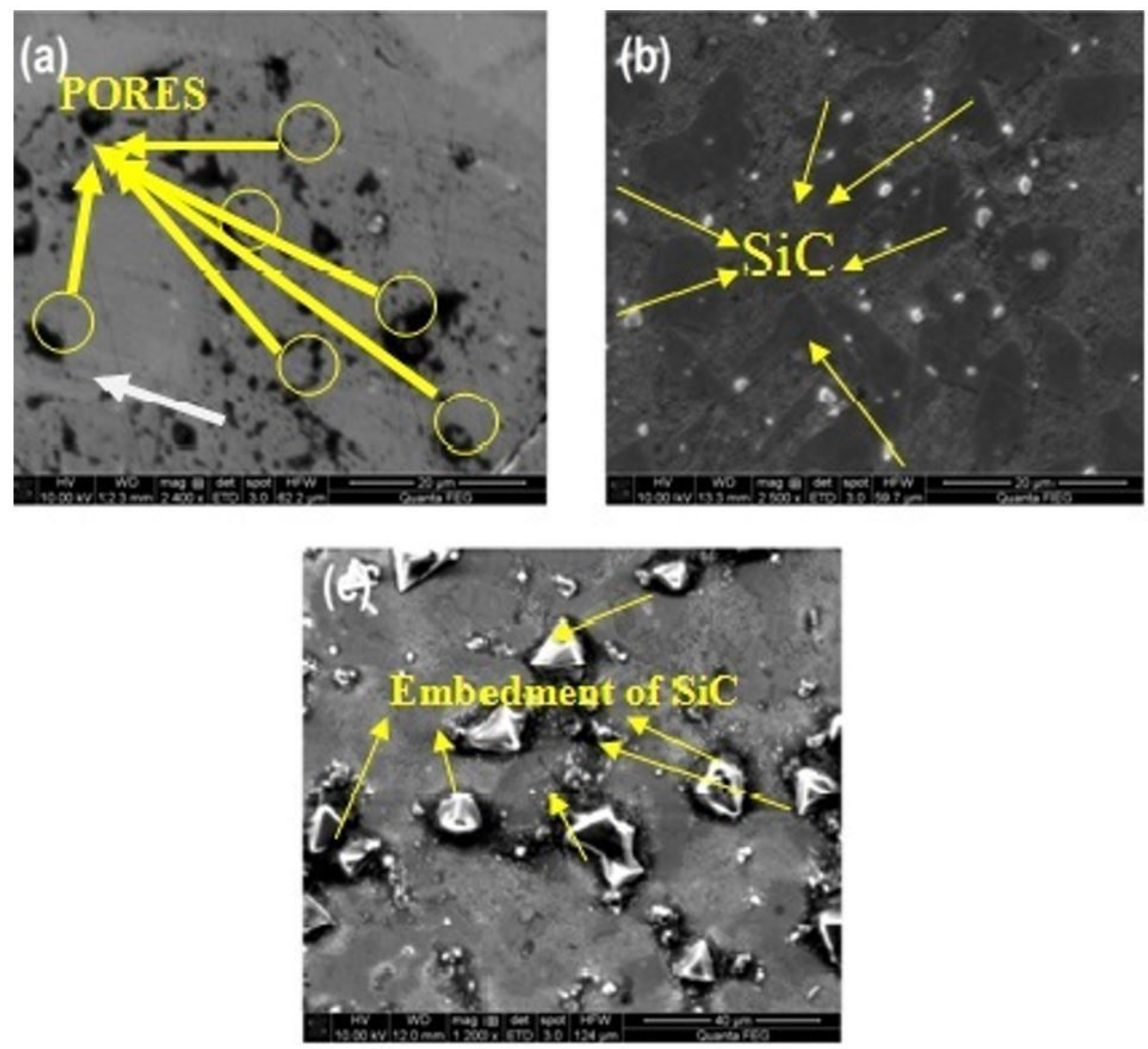

Figure 4

SEM images of sintered aluminium bronze (a) 2 wt.\% SiC composite sintered at 6500 C (b) 2 wt.\% SiC composite sintered at $7500 \mathrm{C}$ (c) $4 \mathrm{wt} . \% \mathrm{SiC}$ composite sintered at $7500 \mathrm{C}$ 
$0 \% \mathrm{SiC}$

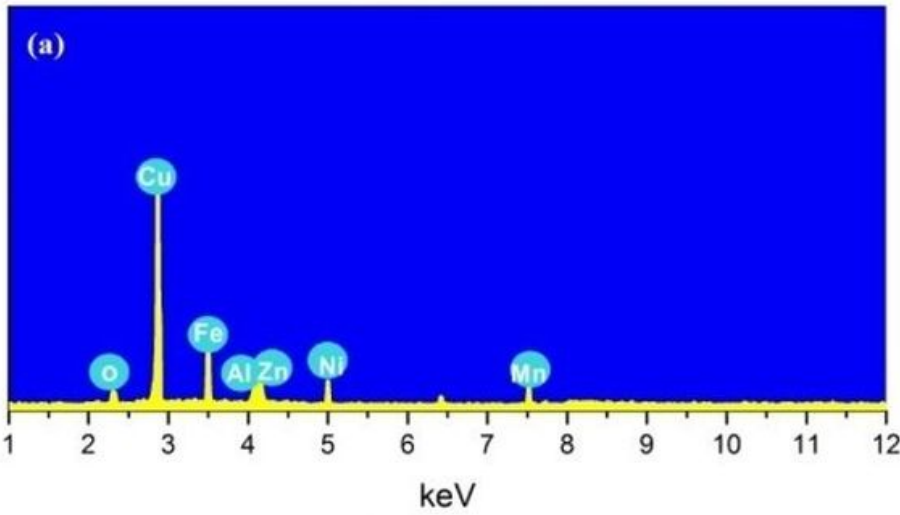

$4 \% \mathrm{SiC}$

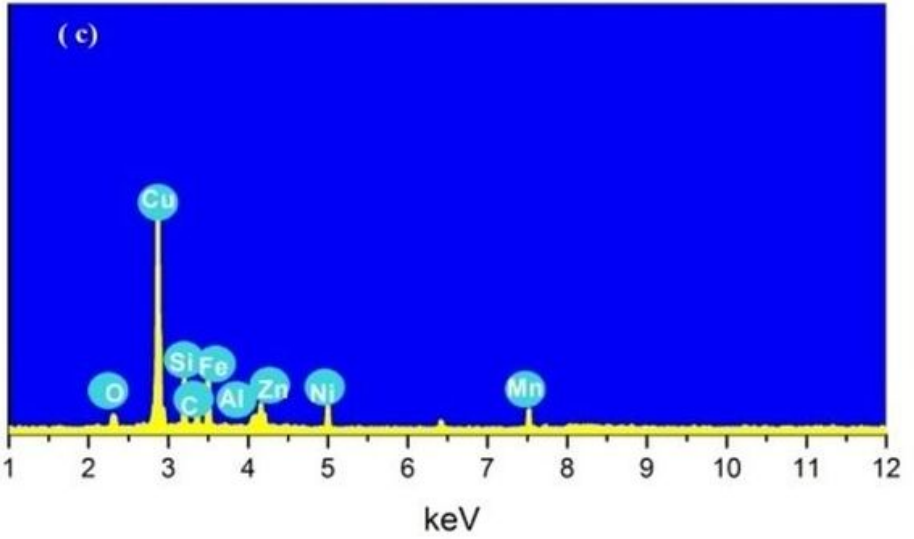

Figure 5

EDS results of sintered aluminium bronze composites
$2 \% \mathrm{SiC}$

(b)

(0)

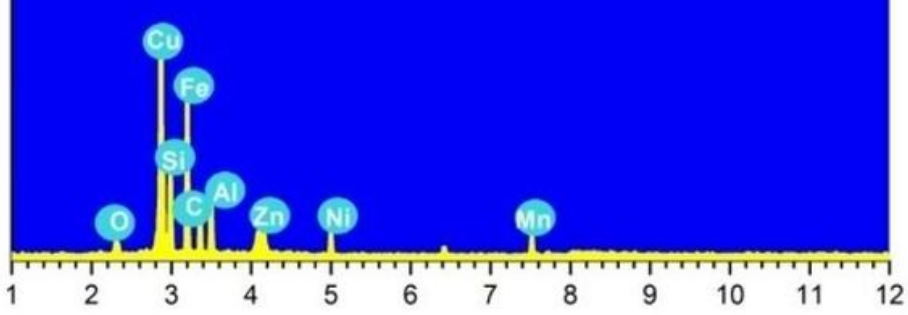

$\mathrm{keV}$

$6 \% \mathrm{SiC}$

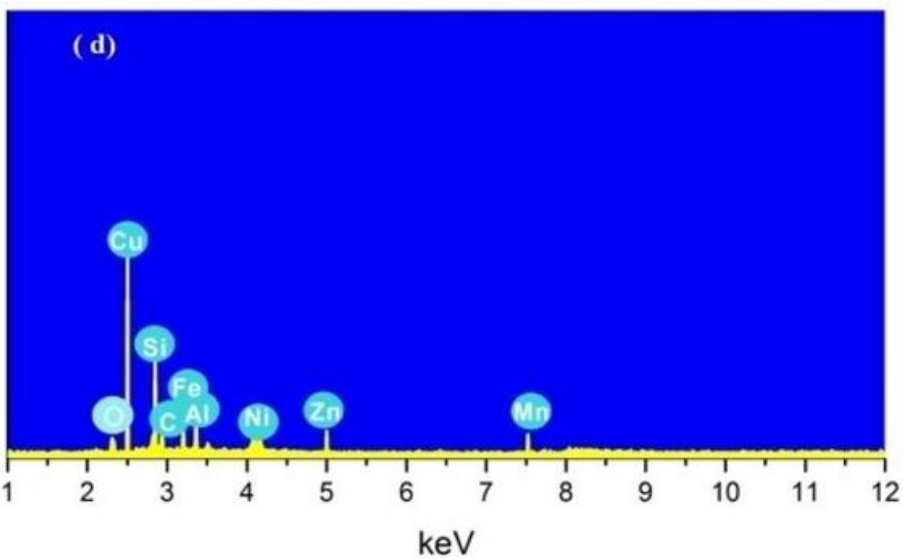




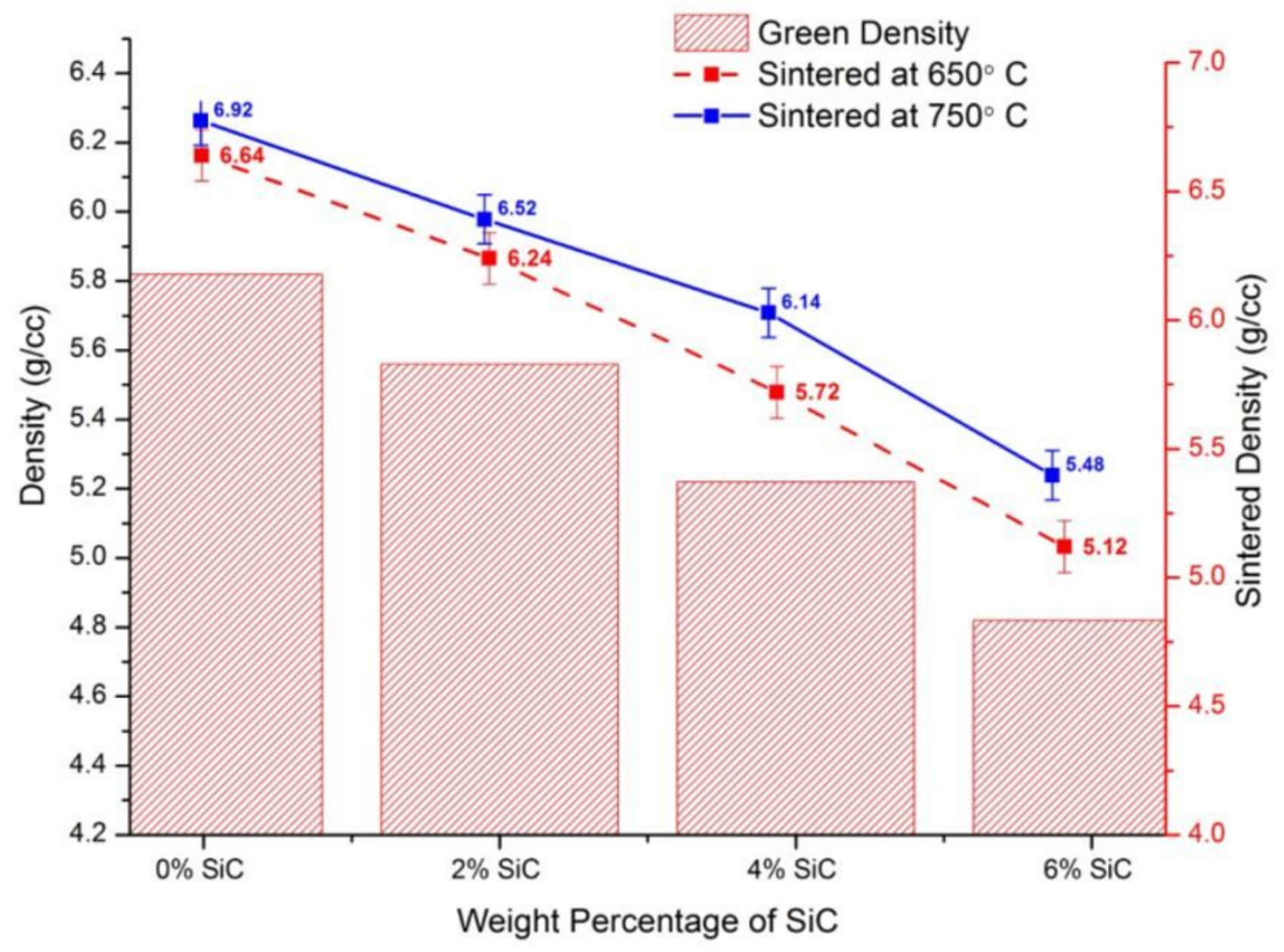

Figure 6

Influence of Sintering temperature on Density 


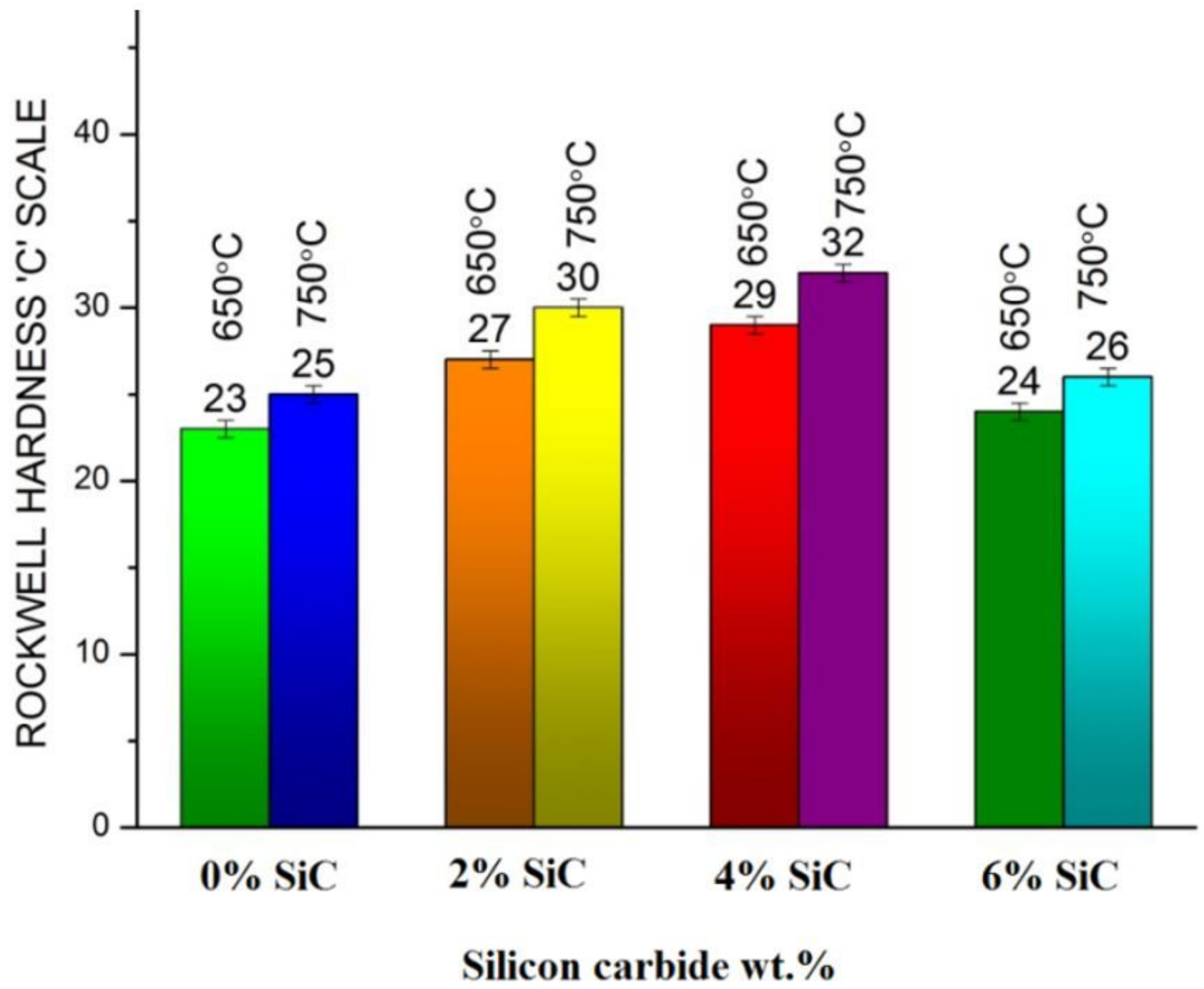

Figure 7

Effect of silicon carbide and sintering temperature in aluminium bronze matrix on hardness 


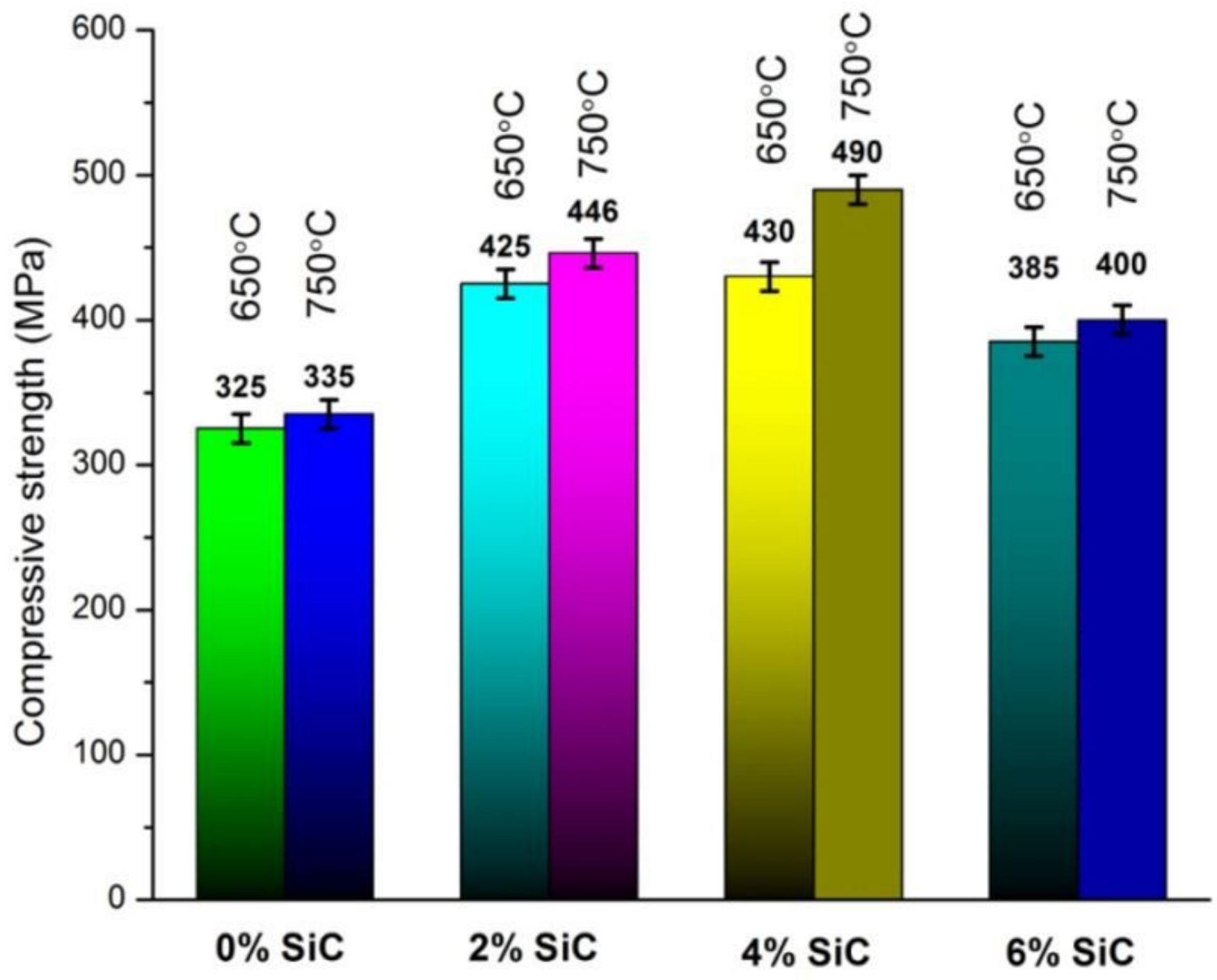

Silicon carbide wt. $\%$

Figure 8

Effect of silicon carbide in aluminium bronze matrix on Compressive strength 


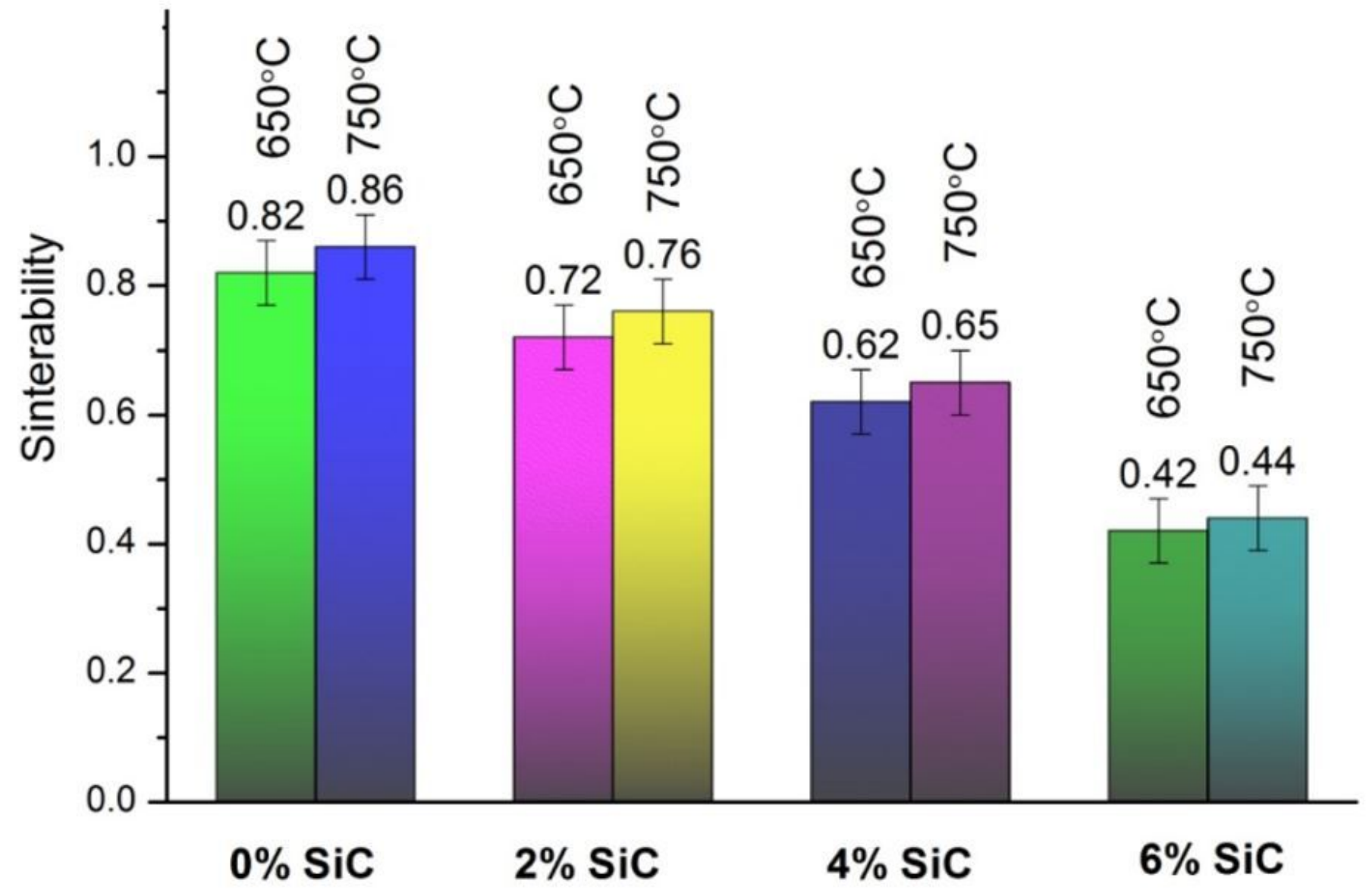

Silicon Carbide wt. \%

Figure 9

Effect of silicon carbide and sintering temperature in aluminium bronze matrix Compressive strength 
(a) $0 \% \mathrm{SiC}$ Composites at $650{ }^{\circ} \mathrm{C}$

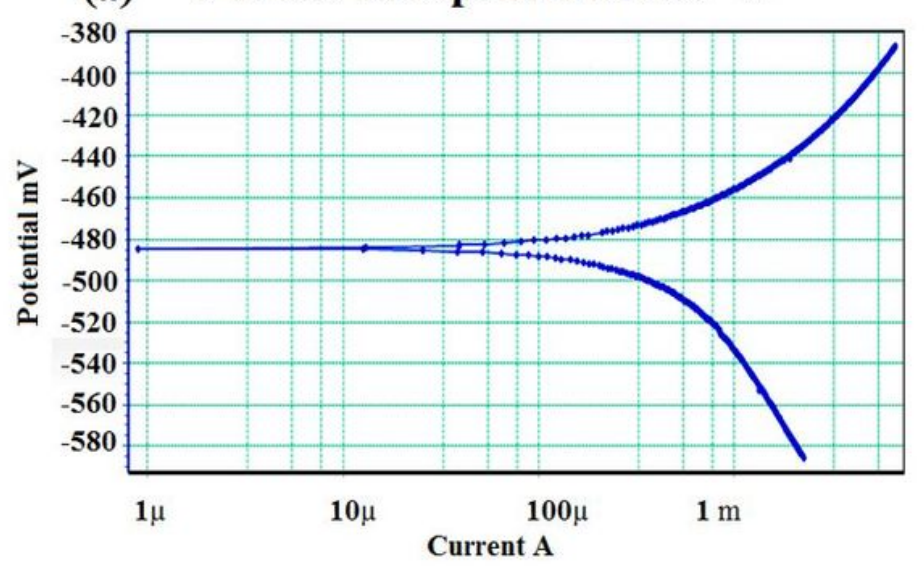

(b) $2 \% \mathrm{SiC}$ Composites at $650{ }^{\circ} \mathrm{C}$

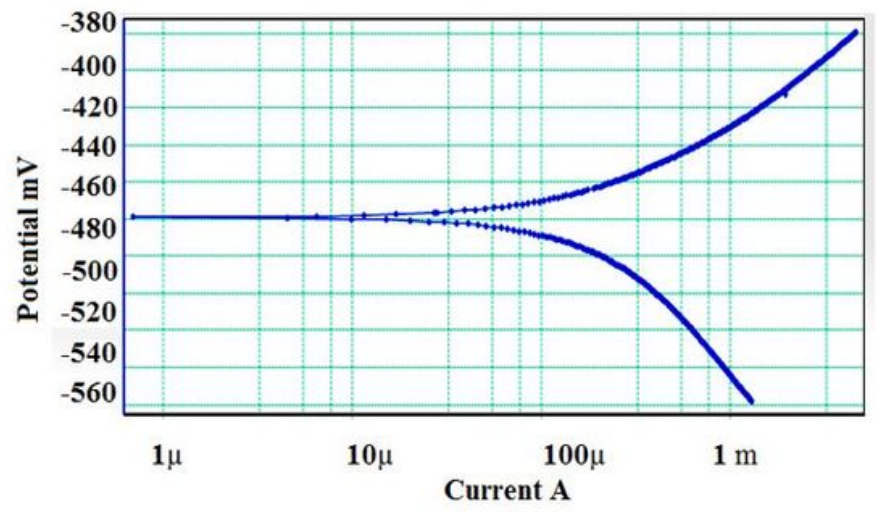

(c) $4 \% \mathrm{SiC}$ Composites at $650{ }^{\circ} \mathrm{C}$

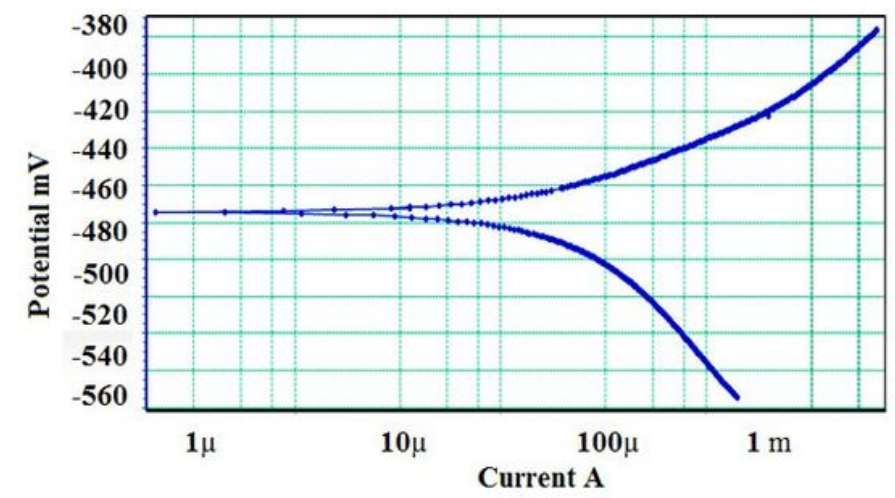

Figure 10

Polarization curves for composites sintered at $6500 \mathrm{C}$ (a) Cu-20\%Al-4\%Ni-0\%SiC (b) Cu-20\%Al-4\%Ni-2\%SiC (c) $\mathrm{Cu}-20 \% \mathrm{Al}-4 \% \mathrm{Ni}-4 \% \mathrm{SiC}$ 

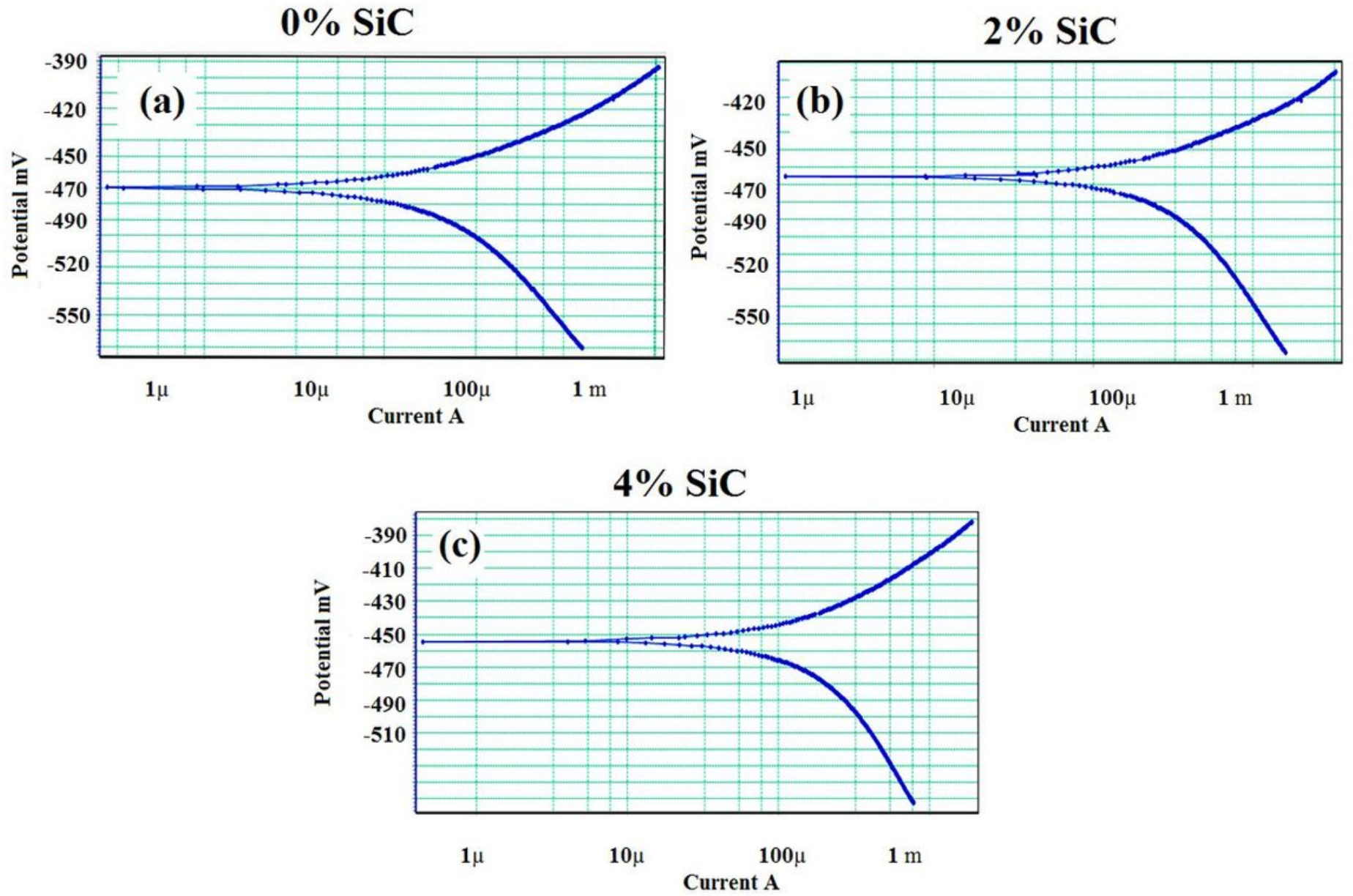

Figure 11

Polarization curves for composites sintered at 7500C (a) Cu-20\%Al-4\%Ni-0\%SiC (b) Cu-20\%Al-4\%Ni-2\%SiC (c) $\mathrm{Cu}-20 \% \mathrm{Al}-4 \% \mathrm{Ni}-4 \% \mathrm{SiC}$ 